\title{
REFORMULASI KEPEMIMPINAN PENDIDIKAN ISLAM DI ERA REVOLUSI INDUSTRI 4.0
}

\author{
Sutrimo Purnomo \\ Institut Agama Islam Negeri Purwokerto \\ sutrimopurnomo92@gmail.com
}

Abstract: This article aims to provide an alternative solution to the world of education in the form of reformulation of Islamic education leadership in the industrial revolution 4.0. Industrial Revolution Era 4.0 is an era marked by the existence of a digital revolution that is a combination of various technologies that blur the lines of physical, digital and biological space. This era has implications for the increasingly sparse space and time and physical activity and communication at a geographical location. Everything changed from a manual to a digital one which turned out to have a significant impact on various lines of people's lives, including in the world of education. If the leadership of Islamic education is unwilling and able to adapt to this era, then Islamic education will be increasingly left behind. For this reason, it is necessary to reformulate Islamic educational leadership, namely through disruptive mindset, self-driving, and reshape or create steps. With these steps the leaders of Islamic education will be able to provide breakthroughs for the development of Islamic education and provide a guarantee of satisfaction for its users. The reformulation of Islamic education leadership also needs to be supported by strengthening users, strengthening strategies, and strengthening information and communication technology based on Islamic and applicable values so that Islamic education is able to answer the hopes and needs of the community, not again limited to education that is sky-high but grounded education.

Keyword: Reformulation, Islamic Education Leadership, and Industrial Revolution Era 4.0.

Abstrak: Artikel ini bertujuan untuk memberikan alternatif solusi kepada dunia pendidikan berupa reformulasi kepemimpinan pendidikan Islam di era revolusi industri 4.0. Era Revolusi Industri 4.0 merupakan era yang ditandai dengan adanya revolusi digital yakni perpaduan berbagai teknologi yang mengaburkan garis ruang fisik, digital, dan biologis. Era ini berimplikasi pada semakin dekatnya jarang ruang dan waktu serta mengurangi aktivitas dan komunikasi secara fisik pada lokasi geografis. Semua berubah dari manual menuju serba digital yang ternyata berdampak signifikan terhadap berbagai lini kehidupan masyarakat, termasuk pada dunia pendidikan. Apabila kepemimpinan pendidikan Islam tidak mau dan mampu beradaptasi dengan era ini, maka pendidikan Islam akan semakin tertinggal. Untuk itu perlu dilakukan reformulasi kepemimpinan pendidikan Islam, yakni melalui langkah disruptive mindset, self-driving, dan reshape or create. Dengan langkah-langkah tersebut para pemimpin pendidikan Islam akan mampu memberikan terobosan-terobosan bagi pengembangan pendidikan Islam dan memberikan jaminan kepuasan bagi para penggunanya. Reformulasi kepemimpinan pendidikan Islam ini juga perlu didukung pula dengan penguatan terhadap user, penguatan strategi, dan penguatan teknologi informasi dan komunikasi yang berlandaskan pada nilai-nilai ke-Islam-an dan applicable sehingga pendidikan Islam mampu menjawab apa yang menjadi harapan dan 
kebutuhan masyarakat, bukan lagi sebatas pada pendidikan yang melangit namun pendidikan yang membumi.

Kata Kunci: Reformulasi, Kepemimpinan Pendidikan Islam, dan Era Revolusi Industri 4.0.

\section{A. PENDAHULUAN}

Perubahan dan perkembangan jaman merupakan sebuah keniscayaan yang ditakdirkan oleh Tuhan untuk semesta alam, termasuk manusia di dalamnya. Ketika manusia tidak mampu mengikuti dan mengadaptasikan dirinya dengan perubahan tersebut walaupun sebenarnya manusia sendirilah sebagai pemicu perubahan, maka ketertinggalanlah yang akan menimpa manusia.

Perubahan dan perkembangan yang terjadi seiring dengan berjalannya waktu berdampak pada semakin terasa singkatnya waktu dan jarak yang tak lagi mengenal batas georgrafis maupun waktu. Revolusi Industri merupakan istilah yang diperkenalkan Friedrich Engels dan Louis Auguste Blanqui sebagai masuknya era digital. Dengan diawali munculnya mesin tenaga uap dan penemuan kekuatan alat tenun yang secara radikal dapat mempercepat produksi barang-barang di mana pada era ini dikenal dengan Era Revolusi Industri 1.0. Setelah itu, berkembanglah listrik dan jalur perakitan yang memungkinkan produksi masal yang dikenal dengan Era Revolusi Industri 2.0. Lalu, muncul berbagai alat dengan otomatisasi bertenaga komputer yang dapat memungkinkan seseorang melakukan pekerjaannya dengan memprogram mesin dan jaringan yang ini dikenal dengan Era Revolusi Industri 3.0.

Saat ini, dunia termasuk Indonesia tengah memasuki era baru sebagai lanjutan dari era-era sebelumnya yang dikenal dengan Era Revolusi Industri 4.0. Era ini ditandai dengan adanya revolusi digital yakni perpaduan berbagai teknologi yang mengaburkan garis ruang fisik, digital, dan biologis. Era ini berimplikasi pada semakin dekatnya jarak ruang dan waktu serta mengurangi aktivitas dan komunikasi secara fisik pada lokasi geografis. Semua berubah dari manual menuju serba digital.

Dengan dimulainya Era Revolusi Industri 4.0 pada abad ini ternyata berdampak signifikan terhadap berbagai lini kehidupan masyarakat, mulai dari ekonomi, dunia kerja, sosial, politik, budaya, termasuk pada dunia pendidikan hingga muncullah istilah Pendidikan 4.0, yakni istilah yang digunakan oleh para ahli pendidikan untuk menggambarkan berbagai cara untuk mengintegrasikan teknologi informasi dan komunikasi yang berkembang saat ini, baik secara fisik maupun non fisik ke dalam kegiatan pembelajaran. (Muhammad Haris, 2019: 47)

Pertama, belajar dapat dilakukan kapan saja dan di mana saja. Kedua, belajar akan bersifat perseorangan untuk tiap siswa. Ketiga, siswa memiliki pilihan dalam menentukan bagaimana mereka ingin belajar. Keempat, siswa akan dihadapkan pada pembelajaran berbasis proyek yang lebih banyak. Kelima, siswa akan dihadapkan pada pembelajaran langsung melalui pengalaman lapangan, seperti: Magang, proyek mentoring dan proyek kolaborasi. Keenam, siswa akan terpapar dengan interpretasi data di mana mereka diminta untuk menerapkan pengetahuan teoritis mereka ke dalam angka dan menggunakan keterampilan penalaran mereka untuk membuat kesimpulan berdasarkan logika serta tren dari set data yang diberikan. Ketujuh, siswa akan dinilai secara berbeda dan platform konvensional untuk menilai siswa dapat menjadi tidak relevan atau tidak memadai. Pengetahuan faktual siswa dapat dinilai selama proses pembelajaran. Adapun aplikasi pengetahuan dapat diuji ketika mereka mengerjakan proyek di lapangan. Kedelapan, pendapat siswa akan dipertimbangkan dalam merancang dan memperbarui kurikulum. Terakhir, siswa akan menjadi lebih mandiri 
dalam pembelajaran, sehingga memaksa para guru untuk mengambil peran baru sebagai fasilitator yang akan memandu siswa melalui proses belajar mereka. (Muhammad Haris, 2019: 45-46)

Hal yang menjadi pertanyaan saat ini, bagaimanakah pendidikan Islam menghadapi tantangan Era Revolusi Industri 4.0 ini yang semuanya serba maya, cepat, dan berlandaskan teknologi informasi, padahal kecenderungan yang ada pendidikan Islam khususnya di Indonesia relatif masih menggunakan cara-cara tradisional dalam kegiatan pembelajarannya. Ini adalah tantangan tersendiri bagi kepemimpinan pendidikan Islam agar mampu menyesuaikan diri dengan berbagai kecanggihan teknologi saat ini agar tujuan pendidikan Islam yang terkonsentrasi tidak hanya pada intelektual yang mumpuni, namun juga pencapaian akhlak yang luhur. Untuk itu, perlu dirumuskan bagaimana kepemimpinan pendidikan Islam yang mampu menyesuaikan diri dengan perubahan dan perkembangan jaman.

\section{B. METODE}

Library research merupakan jenis penelitian yang digunakan dalam riset ini dengan deskriptif eksploratory literature sebagai pendekatan penelitian. Penggunaan pendekatan tersebut dimaksudkan untuk menggali dan melakukan kajian secara mendalam terhadap berbagai literatur khusunya yang berkaitan dengan kepemimpinan kependidikan Islam dan fenomena gelombang industri 4.0. Dari informasi-informasi yang diperoleh, kemudian dilakukan analisis dengan tujuan akhir untuk menemukan kepemimpinan pendidikan Islam yang dapat menyesuaikan perkembangan jaman di era industri 4.0 dengan tajuk reformulasi kepemimpinan pendidikan Islam di era 4.0.

\section{HAKIKAT DAN TUJUAN PENDIDIKAN ISLAM}

Dalam Islam, menuntut ilmu yang sarat kaitannya dengan pendidikan merupakan sebuah kewajiban mutlak bagi setiap insan, bahkan untuk menegaskan akan pentingnya pendidikan, Allah Swt. mentitahkan kepada manusia agar melakukannya dari semenjak manusia lahir ke dunia hingga kembali lagi kepada asal mula ia diciptakan yakni ketika manusia masuk ke dalam liang lahat.

Pendidikan di dalam Islam dikenal dengan beberapa istilah, seperti: Tarbiyah dan Ta'lim. Menurut pendapat Abdurrahman an Nahlawi yang dikutip oleh Heri Jauhari Muchtar (2005: 124) bahwa kata tarbiyah mengandung makna memperbaiki, menguasai urusan, menuntun, menjaga, dan memelihara. Adapun menurut Abdurahman al Bani kata tarbiyah berasal dari kata rabba yang mengandung empat unsur: a. Menjaga dan memelihara fitrah anak menjelang baligh, b. Mengembangkan seluruh potensi dan kesiapan bermacam-macam hal, c. Mengerahkan seluruh fitrah dan potensi ini menuju kebaikan dan kesepurnaan yang layak baginya, dan d. Proses ini dilaksanakan secara bertahap.

Adapun ta'lim mengandung arti upaya agar berilmu. Menurut Islam, ilmu itu mengandung segala kemaslahatan bagi umat manusia. Karena ilmulah manusia menjadi lebih utama dari pada malaikat dan karena ilmu pula manusia berhak menjadi khalifah Allah di muka bumi.

Imam al Ghazali (dalam Heri Jauhari Muchtar, 2005: 125) menyatakan bahwa ilmu adalah keutamaan dan pencapaian ilmu sudah merupakan tujuan pendidikan. Mengenai pengajaran dan pendidikan, Imam al Ghazali mengarahkannya pada dua sasaran, yakni kesempurnaan insan dengan taqarrub kepada Allah Swt dan memperoleh kebahagiaan dunia serta akhirat sehingga pada hakikatnya pendidikan Islam merupakan:

a. Proses yang pasti, karena bersumber dari sifat Allah Yang Maha Mendidik yang menciptakan manusia secara fitrah selalu menginginkan kemajuan terusmenerus. 
b. Proses yang tetap, karena bersumber dari Allah Swt dan berproses sesuai dengan sunnatullah dan tidak bergeser sedikitpun.

c. Proses yang objektif, karena pendidikan berlaku untuk segenap umat manusia. Tidak bergantung kepada apa dan bagaimana status sosialnya di muka bumi.

d. Memelihara ketauhidan umat manusia terhadap Allah Swt yang merupakan inti dari hidup dan kehidupan umat manusia, karena tujuan hidup umat manusia adalah untuk beribadah kepada Allah Swt.

Pendidikan Islam juga merupakan konsep 'allama maa lam ya'lam (Allah mengajarkan segala sesuatu yang tidak diketahui manusia). Hal tersebut mengandung pengertian bahwa Allah mengajarkan suatu pengetahuan baru kepada manusia setiap saat. Karena itu, manusia dituntut untuk belajar tentang apa saja sepanjang hidupnya dan hendaknya selalu berdialog dengan perkembangan jaman. Lebih jauh ayat tersebut menjelaskan nilai semua pengetahuan menurut al Qur'an adalah sama pentingnya. Islam tidak mengenal pembedaan ilmu antara ilmu pengetahuan agama dan ilmu pengetahuan non agama (sekuler). Selama pengetahuan itu bernilai baik, selama itu pula ia bernilai kegamaan (Heri Jauhari Muchtar, 2005: 125).

Selain itu, konsep ilmu dalam Islam sebagai salah satu unsur pendidikan hendaknya mengacu kepada lingkungan dan kebutuhan masyarakat. Karena itu harus bersifat applicable (asas manfaat). Hal ini dapat dilacak dari beragamnya pengetahuan yang diberikan Allah kepada para Nabi dan umat mereka. Walaupun ragamnya berbeda, semua memiliki nilai yang sama, yaitu diarahkan untuk mengenal Allah Swt dengan segala sifat-sifat-Nya sehingga manusia selalu merasa di dekat-Nya dan mampu mengubah dunia sesuai kebutuhan manusia sekaligus melestarikannya. Pengenalan pengetahuan pada saat yang sama merupakan penanaman dan pembentukan serta pengembangan nilai-nilai yang mencerahkan, mengantarkan manusia kepada kehidupan yang takwa dan dapat menjauhkan dari kehidupan yang fahsya dan munkar.

Selanjutnya, segala sesuatu tentunya memiliki tujuan yang hendak dicapai. Makna tujuan sendiri ialah sesuatu yang diharapkan tercapai setelah suatu usaha atau kegiatan selesai (Bukhari Umar, 2010: 52). Tujuan juga merupakan sesuatu yang esensial bagi kehidupan manusia. Dengan adanya tujuan, semua aktifitas dan gerak manusia menjadi lebih dinamis, terarah, dan bermakna (Samsul Nizar, 2008: 116).

Adapun tujuan pendidikan Islam pada umumnya ialah untuk membina manusia agar menjadi hamba Allah yang saleh dengan seluruh aspek kehidupannya, perbuatan, pikiran, dan perasaannya (Zakiah Daradjat, 1995: 35). Selain itu, tujuan umum lainnya adalah membentuk kepribadian sebagai khalifah Allah atau sekurang-kurangnya mempersiapkan ke jalan yang mengacu kepada tujuan akhir/ utama manusia. Tujuan utama khalifah Allah adalah beriman kepada Allah dan tunduk patuh secara total kepada-Nya (Abdurrahman Saleh Abdullah, 1990: 133).

Tujuan pendidikan Islam menurut para ahli sebagaimana dikutip oleh Moh. Roqib (2009: 27-30, Lihat pula Mahmud Yunus, t.t.: 22 dan Juwariyah, 2010: 16, di mana keduanya menekankan akhlak sebagai tujuan pendidikan Islam) antara lain sebagai berikut:

a. Naquib al Attas menyatakan bahwa tujuan pendidikan yang penting harus diambil dari pandangan hidup. Jika pandangan hidup itu Islam maka tujuannya adalah membentuk manusia sempurna menurut Islam (insane kamil).

b. Mohammad Athiyah al Abrasyi merumuskan tujuan pendidikan Islam secara lebih rinci. Dia menyatakan bahwa tujuan pendidikan Islam adalah untuk membentuk akhlak mulia, persiapan untuk menghadapi kehidupan dunia dan akhirat, persiapan untuk mencari rizki, menumbuhkan semangat ilmiah, dan menyiapkan profesionalisme subyek didik. 
c. Ahmad Fuad al Ahwani menyatakan bahwa pendidikan Islam adalah perpaduan yang menyatu antara jiwa, membersihkan ruh, mencerdaskan akal, dan menguatkan jasmani. Fokus di sini adalah keterpaduan atau integrasi

d. Umar Muhammad at Taumi asy Syaibani mengemukakan pendapat bahwa tujuan tertinggi dari pendidikan Islam adalah persiapan untuk kehidupan dunia dan akhirat, yakni untuk memproses manusia yang siap untuk berbuat dan memakai fasilitas dunia ini guna beribadah kepada Allah.

Dari berbagai gagasan tujuan pendidikan tersebut dapat ditarik benang merah bahwasannya tujuan pendidikan Islam secara umum menitik beratkan pada akhlak seseorang, baik akhlak kepada Sang Pencipta, sesama, maupun terhadap lingkungan dan semesta. Ketika seseorang telah mampu dan menyadari hakikat penciptaan dirinya serta melaksanakan apa yang menjadi tugas dan kewajibannya, maka pada saat itu tujuan pendidikan Islam telah tercapai dalam dirinya. Seyogyanya pula setiap lembaga pendidikan Islam khususnya bagi para pemimpin dan pemegang kebijakan mampu mengarahkan para peserta didiknya untuk mencapai tujuan tersebut.

\section{KEPEMIMPINAN PENDIDIKAN ISLAM IDEAL}

Kepemimpinan pendidikan Islam memiliki peran strategis bagi pencapaian tujuan yang telah dicitakan di mana hal tersebut sangat dipengaruhi oleh sosok pemimpin di dalamnya. Terdapat beberapa kriteria pemimpin ideal dalam pandangan Islam, sebagai berikut:

a. Adil, yaitu yang meletakan segala sesuatu secara proporsional, tertib, dan disiplin. Ia tidak berat sebelah, tidak pilih-pilih bulu, dan bijaksana dalam mengambil keputusan.

b. Amanah, artinya jujur, bertanggungjawab, dan mempertanggungjawabkan seluruh titipan aspirasi masyarakat atau bawahannya. Tidak melakukan penghianatan kepada rakyatnya.

c. Fathanah, artinya memiliki kecerdasan.

d. Tablig, artinya menyampaikan segala sesuatu dengan benar, tidak ada yang ditutup-tutupi, terbuka, dan menerima saran atau kritik bawahannya.

e. Shidiq, artinya benar atau jujur, sebagai ciri dari perilaku pemimpin yang adil, apa yang dikatakan sama dengan apa yang dilakukan.

f. Qana'ah, artinya menerima apa adanya, tidak serakah, dan pandai berterimakasih kepada Tuhan. Pemimpin yang qana'ah adalah pemimpin yang tidak akan melakukan korupsi dan merugikan uang negara, mengambinghitamkan masyarakat, dan anak buahnya.

g. Siyasah, artinya pemimpin yang pandai mengatur strategi guna memperoleh kemaslahatan bagi masyarakat atau anak buahnya.

h. Sabar, artinya pandai mengendalikan hawa nafsu dan menyalurkan seluruh tenaga serta pikirannya dengan kecerdasan emosional yang optimal (Beni Ahmad Saebani, 2012: 299-300, lihat pula Mulyono, 2012: 11 dan Imam al Mawardi yang dikutip oleh Muhadi Zainuddin dan Abd. Mustaqim, 2012: 3739 yang keduanya membahas pula idealitas kepemimpinan pendidikan Islam).

Mujamil Qomar (2007: 277) mengungkapkan bahwa jabatan pemimpin merupakan jabatan yang istimewa sebab, pemimpin organisasi apapun dipersyaratkan memiliki berbagai kelebihan menyangkut pengetahuan, perilaku, sikap, maupun keterampilan dibanding orang lain. Pada umumnya, seseorang memiliki kelebihankelebihan tertentu, tetapi sebaliknya juga memiliki kelemahan-kelemahan tertentu.

Figur pemimpin yang ideal sangatlah diharapkan oleh masyarakat, lantaran seorang pemimpin menjadi contoh terbaik dalam segala ucapan, perbuatan, dan 
kebiasaan, termasuk dalam hal berpakaian. Dalam konteks pendidikan Islam, pemimpin harus memiliki keunggulan yang lebih lengkap. Dasar filosofinya adalah pendidikan Islam yang memiliki tugas sebagai lembaga yang berusaha keras untuk membangun umat tidak hanya pada kecerdasan intelektual, namun juga kesalehan sosial dan kemantapan spiritual.

\section{E. REFORMULASI KEPEMIMPINAN PENDIDIKAN ISLAM DI ERA 4.0}

Al Islaamu ya'lu wa laa yu'laa 'alaih, Islam adalah agama yang unggul dan tidak dapat diungguli oleh yang lainnya. Ini adalah ungkapan bagaimana hebatnya agama Islam hingga tidak ada yang mampu mengunggulinya. Sekali lagi, pada dasarnya Islam adalah agama yang unggul, namun bagaimana dengan umat Islam, terlebih bagaimana dengan pendidikan Islam.

Syamsul Ma'arif (2007) menyebutkan bahwa pendidikan Islam saat ini masih jauh tertinggal dengan Barat. Hal tersebut disebabkan oleh beberapa hal, antara lain: Pertama, orientasi pendidikan Islam masih harus diperjelas arahnya pada tujuan yang semestinya sesuai dengan orientasi Islam. Saat ini, pendidikan Islam hanya concern pada transfer pengetahuan keagamaan semata. Kedua, praktik pendidikan Islam masih memelihara warisan lama, sehingga ilmu yang dipelajari adalah ilmu klasik dan ilmu modern tidak tersentuh. Ketiga, umat Islam masih sibuk terbuai dengan romantisme masa lalu. Kebesaran umat Islam masa lampau sampai saat ini masih mempengaruhi mindset umat Islam. Mereka masih berbangga dengan kejayaan masa lalu, tetapi tidak sadar bahwa kebanggan itu justru hal yang menyebabkan ketertinggalan. Keempat, model pembelajaran pendidikan Islam masih menekankan pada pendekatan intelektual verbalistik dan menegasi interaksi edukatif dan komunikasi humanistic antara pendidik dan peserta didik.

Untuk itu, terdapat dua alasan mendasar perlu dilakukannya modernisasi pendidikan Islam, yaitu:

Pertama, konsep dan praktik pendidikan. Islam selama ini terlalu sempit yang terlalu menekankan pada kepentingan akhirat sehingga melahirkan dikotomi keilmuan yang telah diwariskan ummat Islam sejak masa kemunduran Islam (abad kedua belas). Adapun dikotomi keilmuan dalam pendidikan Islam meliputi 1. Dikotomi antara ilmu agama dan non agama, yang berdampak pada pelanggengan supremasi ilmu-ilmu agama yang berjalan secara monoton, 2. Dikotomi antara wahyu dan alam yang menyebabkan kemiskinan penelitian empiris dalam pendidikan Islam, dan 3. Dikotomi antara iman dan akal. Dalam konten ini, Islam harus diyakini sebagai religion of nature, yang dengannya segala bentuk dikotomi antara agama dan ilmu pengetahuan dihilangkan. Alam beserta isinya mengandung tanda-tanda yang memperlihatkan kebesaran Tuhan yang menggambarkan kehadiran kesatuan sistem global yang dengan mendalaminya, seseorang akan mampu menangkap makna dan kebijaksanaan dari suatu yang transenden

Kedua, lembaga-lembaga pendidikan Islam sampai saat ini, belum mampu memenuhi kebutuhan umat Islam secara keseluruhan terutama dalam menghadapi tantangan dunia modern dan tantangan masyarakat serta bangsa Indonesia di segala bidang (Hasan Langgulung, 1988).

Oleh sebab itu, untuk menghadapi dan menyongsong Era Revolusi Industri 4.0 yang tengah berjalan saat ini diperlukan adanya reformulasi kepemimpinan pendidikan Islam yang mampu menjawab berbagai permasalahan dan dinamika pendidikan Islam serta mampu menyesuaikan dan memanfaatkan berbagai perkembangan teknologi di era ini menuju kebangkitan dan tercapainya tujuan pendidikan Islam. 
Dengan meminjam istilah yang digunakan oleh Rhenald Kasali (2017), perlu dilakukan tiga langkah oleh para pemimpin pendidikan Islam dalam menghadapi era 4.0 ini, yaitu: disruptive mindset, self-driving, dan reshape or create.

Disruptive mindset. Mindset ialah bagaimana manusia berpikir dengan ditentukan oleh setting yang dibuat sebelum berpikir dan bertindak. Pendidikan Islam hari ini tengah berada di zaman digital yang serba cepat, mobilitas tinggi, akses informasi menjadi kebutuhan primer bagi setiap orang. Segala sesuatu yang diperlukan haruslah segera tersedia, jika dalam aksesnya memerlukan waktu yang relatif lama, maka masyarakat akan meningggalkannya dan beralih ke pelayanan lain yang lebih cepat dan akses mudah. Kecepatan respon akan sangat berpengaruh terhadap pengguna (user). Inilah yang dinamakan Rhenald Kasali sebagai corporate mindset (mindset korporat). Mindset ini perlu dibangun oleh para pelaku pendidikan Islam terutama pemimpin lembaga pendidikan Islam sebagai kompas dalam perjalanannya sehingga pelayanan yang diberikan kepada user tidak lagi birokratis.

Rhenald mengungkapkan beberapa ciri orang yang memiliki mindset korporat, yaitu: Pertama, tidak terikat waktu dan tempat. Orang tersebut bekerja tidak terbatas pada jam dan ruang kerja. Orang seperti ini telah menyadari bahwa waktu dan tempat tidak lagi menjadi penghalang dalam bekerja. Jika mindset ini diterapkan dalam manajemen lembaga pendidikan Islam, maka akan terbentuk sistem manajerial yang efektif dan efisien. Selanjutnya, apabila hal tersebut ditarik dalam konteks pembelajaran, guru akan lebih leluasa dan fleksibel dalam menjalankan tugas dan fungsinya. Kedua, memberikan pelayanan yang proaktif. Kegiatan pembelajaran yang masih terkonsentrasi pada transfer pengetahuan yang dilakukan oleh guru dan terkurung di dalam kelas, maka hal tersebut akan sulit menghasilkan lulusan yang berdaya saing tinggi. Paradigma pendidikan kini telah berubah, bukan lagi berupa teacher centered, tapi sudah beralih menjadi student centered. Guru dituntut untuk lebih proaktif dalam memberikan fasilitas, bimbingan, dan dampingan kepada peserta didik.

Ketiga, tidak terpaku pada anggaran atau biaya. Orang yang memiliki mindset korporat tidak berhenti berinovasi karena kendala dana. Keempat, memaksimalkan fungsi media sosial. Pengelola pendidikan Islam saat ini harus mampu memanfaatkan kemajuan media komunikasi yang tersedia. Media sosial bukan lagi hiburan semata. Ia telah menjelma menjadi alat komunikasi yang efektif, alat bantu kerja, dan inspirasi dalam berinovasi. Peluang ini harus mampu dimanfaatkan dengan baik oleh para pimpinan lembaga pendidikan Islam. Kelima, berpikir solutif jika dihadapkan pada masalah dan bukan sibuk memikirkan alasan untuk menyelematkan diri. Keenam, tidak alergi terhadap adanya perubahan. Justru di era saat ini, perubahan telah menjadi kebutuhan. Suatu lembaga jika tetap bertahan dalam pengelolaannya akan kalah dengan lembaga yang pengelolaannya lebih dinamis. Ketujuh, berpikir dan bertindak strategik. Langkah dalam pengelolaan lembaga pendidikan Islam harus memiliki roadmap yang jelas. Sasaran yang dicanangkan harus realistis dan terukur. Untuk itu, reorientasi kurikulum dan visi pendidikan Islam penting untuk dilakukan. Kurikulum, visi, program tahunan, program semester harus jelas, fleksibel, kontekstual, dan futuristik.

Self-Driving. Organisasi yang tangkas dan dinamis dalam menyesuaikan diri terhadap disruption adalah organisasi yang memiliki Sumber Daya Manusia (SDM) bermental pengemudi yang baik (good drivers) bukan penumpang (passanger). SDM yang bermental good driver akan membuka diri, cepat dan tepat membaca situasi, berintegritas, tangkas dalam bertindak, waspada terhadap segala kemungkinan buruk serta mampu bekerja secara efektif, inovatif, dan efisien. Kemampuan-kemampuan tersebut dibutuhkan oleh para pemimpin dan pengelola lembaga pendidikan Islam. Mereka dituntut agar mampu menjadi pengemudi yang handal bagi lembaganya. Oleh karena itu, kompetensi manajerial saja belumlah cukup dan harus diiringi dengan 
kemampuan memimpin. Sementara SDM yang bermental penumpang akan cenderung birokratis, kaku, lambat, dan kurang disiplin.

Reshape or Create. Terdapat sebuah analogi pemikiran yang populer di kalangan umat Islam yang hingga saat ini masih dipegang teguh, yaitu mempertahankan yang lama yang baik dan mengambil yang baru yang lebih baik. Di era revolusi industri 4.0 perlu adanya perombakan yang tidak sedikit mulai dari tataran manejemen dan profesionalitas SDM yang memerlukan peningkatan kompetensi dan kapasitasnya. Hal tersebut dapat dilakukan dengan berbagai cara, antara lain melalui diklat pelatihan, seminar, loka karya, beasiswa studi, dan sebagainya. Cara lain untuk menyikapi era revolusi industri 4.0 dapat dilakukandengan cara create, menciptakan hal yang baru yang benar benar belom ada sebelumnya. Dengan kata lain bahwa sistem yang lama telah exspired. Sistem yang usang diganti dengan sistem baru seperti mengembangkan sistem pelayanan berbasis digital sehingga warga lembaga pendidikan Islam mampu dengan leluasa mengakses dan memanfaatkan segala keperluan terkait pendidikan dan layanan administrasi. Contoh lain seperti dengan mengembangkan model pembelajaran kekinian yang memanfaatkan teknologi digital, seperti e-learning, blended learning, dan lain sebagainya.

Menurut hemat penulis, sudah saatnya pendidikan Islam terutama para pemimpin lembaganya untuk mau membuka diri dengan perubahan dan perkembangan era yang ada. Al islaamu shalihun likulli zaman wa makan, Islam adalah agama yang selalu sesuai dan cocok untuk setiap era dan tempat termasuk di era 4.0 ini. Ketika para pemimpin pendidikan Islam tidak mau mengikuti dan beradaptasi dengan perubahan yang ada, maka umat Islam akan semakin tertinggal dengan kemajuan yang ada.

Oleh karena itu, bagi para pemimpin lembaga pendidikan Islam perlu merubah, baik pikiran/ mindset, perilaku, dan perasaan sebagaimana yang dipaparkan oleh Rhenald Kasali untuk mampu mengikuti perkembangan jaman. Terdapat beberapa hal yang perlu menjadi fokus utama dalam melakukan reformulasi kepemimpinan pendidikan Islam di era 4.0 ini, antara lain:

Pertama, penguatan user. User atau pengguna di sini ialah masyarakat secara luas yang menggunakan jasa pendidikan Islam. Masyarakat perlu diberi edukasi tentang tujuan pendidikan Islam yang akan dicapai dengan menggunakan sarana-sarana yang serba berbau teknologi tanpa menghilangkan nilai ke-Islam-an di dalamnya. Agar dapat bernilai jual, kualitas yang dibangun pun seyogyanya tidak sebatas dari sudut pandang produsen dalam hal ini lembaga pendidikan Islam, namun sudah mulai merambah pada apa yang menjadi harapan dan keinginan masyarakat sehingga orientasi mutu yang dibangun akan bersifat applicable sesuai dengan kebutuhan masyarakat. Lembaga pendidikan Islam perlu menanyakan secara langsung apa yang menjadi kebutuhan masyarakat saat ini sehingga dalam merumuskan tujuan dan prosesnya akan sesuai dengan jawaban yang diharapkan oleh masyarakat. Untuk itu, perlu dibangun mindset bahwa mutu adalah apa yang menjadi harapan dan kebutuhan masyarakat.

Kedua, penguatan strategi. Kepemimpinan lembaga pendidikan Islam di era 4.0 ini tidak lagi sebatas pada bagaimana agar lembaga yang dipimpinnya dapat tetap eksis, namun harus lebih dari sekedar eksis. Kepemimpinan lembaga pendidikan Islam era 4.0 ini harus mampu berorientasi bagaimana pendidikan Islam mampu bersaing dan bahkan menyaingi pendidikan-pendidikan lain terutama pendidikan Barat yang saat ini tengah berjaya yang tentunya dengan bercirikhas ke-Islam-an. Dengan demikian momentum era 4.0 ini dapat menjadi pijakan untuk mengembalikan kejayaan ilmu pengetahuan Islam. Seorang pemimpin lembaga pendidikan Islam pun harus mampu memberikan teladan bagi para anggotanya untuk mau belajar dalam penguasaan teknologi dengan memberikan berbagai macam stimulus yang tentunya pemimpin tersebut harus mampu menggunakan teknologi yang ada terlebih dahulu. Selain itu, pendidikan Islam juga 


\section{Sutrimo}

perlu diarahkan untuk menjawab permasalahan yang riil ada di kehidupan, bukan sebatas teori atau konsep sehingga perlu dirancang kurikulum pendidikan Islam beserta sarana pembelajaran penunjang lainnya yang mampu menjawab permasalahan praktis di masyarakat.

Ketiga, penguatan teknologi, sistem informasi dan komunikasi. Pemimpin lembaga pendidikan Islam seyogyanya mulai menyiapkan sarana dan prasarana pembelajaran berbasis teknologi dengan tanpa meninggalkan sarana dan tradisi lama yang telah sesuai bagi pencapaian tujuan pendidikan Islam. Pemenuhan kebutuhan teknologi dalam pembelajaran ini penting diwujudkan sebagai upaya mengikuti dan beradaptasi terhadap kemajuan di era 4.0. Sistem informasi dan komunikasi yang dapat melayani dengan cepat, tepat, dan efektif pun perlu dibangun demi menunjang penyesuaian terhadap era 4.0 dalam dunia pendidikan. Semua sistem yang dibangun diarahkan pada pencapaian tujuan pendidikan yang tidak sekedar pemuasan terhadap rasa haus intelektual, namun hal yang lebih utama ialah peningkatan kualitas akhlak. Segala teknologi, sistem informasi dan komunikasi yang dibangun dilandaskan bagi pencapaian tujuan pendidikan Islam itu sendiri.

Revolusi industri 4.0 dengan disruptive innovation-nya menempatkan pendidikan Islam termasuk kepemimpinan para pengambil kebijakan di dalamnya dalam perjuangan eksistensi yang kuat dan ketat. Perjuangan tersebut membawa dampak dan implikasi yang beragam. Penyelenggara Pendidikan Islam berhak untuk memilih dan memposisikan dirinya dan sudah saatnya pendidikan Islam mau membuka diri dan menerima era disrupsi dengan segala konsekuensinya, maka ia akan mampu turut bersaing dengan yang lain. Bagi para pemimpin lembaga pendidikan Islam perlu disadari bahwa dalam mengikuti perkembangan era ini dengan segala perkembangan teknologi dan komunikasi, nilai-nilai Islam perlu menjadi landasan dalam pengembangannya agar jangan sampai para generasi Islam melek teknologi, unggul intelektual, namun miskin akan moral dan ketika itu terjadi sesungguhnya bukan keberhasilan yang dicapai, namun justru kegagalan pendidikan Islam itu sendiri.

\section{F. SIMPULAN}

Reformulasi kepemimpinan pendidikan Islam di era revolusi industri 4.0 perlu dilakukan agar pendidikan Islam tidak hanya sebatas mampu menjaga eksistensinya, namun juga mampu berdaya saing di kancah pendidikan global dengan tujuan utama peningkatan kualitas akhlak yang diimbangi dengan intelektual yang unggul bagi para generasi Islam. Terdapat beberapa langkah yang perlu dilakukan untuk mereformulasi kepemimpinan pendidikan Islam di era 4.0 ini, yaitu: disruptive mindset, self-driving, dan reshape or create. Dengan langkah-langkah tersebut para pemimpin pendidikan Islam akan mampu memberikan terobosan-terobosan bagi pengembangan pendidikan Islam dan memberikan jaminan kepuasan bagi para penggunanya.

Reformulasi kepemimpinan pendidikan Islam ini juga perlu didukung pula dengan penguatan terhadap user, penguatan strategi, dan penguatan teknologi informasi dan komunikasi yang berlandaskan pada nilai-nilai ke-Islam-an dan applicable sehingga pendidikan Islam mampu menjawab apa yang menjadi harapan dan kebutuhan masyarakat, bukan lagi sebatas pada pendidikan yang melangit namun lupa bahwa ia ada di bumi. Akhirnya, revolusi industri 4.0 dengan disruptive innovation-nya menempatkan pendidikan Islam dan kepemimpinan para pengambil kebijakan di dalamnya dalam perjuangan eksistensi yang kuat dan ketat. Perjuangan tersebut membawa dampak dan implikasi yang beragam. Penyelenggara pendidikan Islam sudah saatnya untuk memilih dan memposisikan dirinya untuk mau membuka diri dan menerima era disrupsi dengan tanpa meninggalkan akar ke-Islam-annya agar ia akan mampu mewujudkan tujuan pendidikan Islam dan berdaya saing dengan yang lain. 
Reformulasi Kepemimpinan Pendidikan Islam di Era Revolusi Industri 4.0 


\section{DAFTAR PUSTAKA}

Abdullah, Abdurrahman Saleh. 1990. Teori-teori Pendidikan Berdasarkan Al-Qur'an, Terj. M. Arifin dan Zainuddin. Jakarta: PT Rineka Cipta.

Daradjat, Zakiah. 1995. Pendidikan Islam dalam Keluarga dan Sekolah. Jakarta: Ruhama.

Muhammad, Haris. 2019. Manajemen Lembaga Pendidikan Islam dalam Menghadapi Revolusi Industri 4.0. Jurnal Manajemen Pendidikan, 1 (1): 45-57.

Indrafachrudi, Seokarto dkk.1993. Pengantar Kepemimpinan Pendidikan, Surabaya: Usaha Offset Printing.

Juwariyah. 2010. Dasar-dasar Pendidikan Anak dalam Al-Qur'an. Yogyakarta: Teras.

Kasali, Rhenald. 2017. Disruption "Tak Ada yang Tak Bisa Diubah Sebelum Dihadapi Motivasi Saja Tidak Cukup” Menghadapi Lawan-Lawan Tak Kelihatan dalam Peradaban Uber. Jakarta: PT Gramedia Pustaka Utama.

Langgulung, Hasan. 1988. Pendidikan Islam. Jakarta: Pustaka Al-Husna.

Ma’arif, Syamsul. 2007. Revitalisasi Pendidikan Islam. Yogyakarta: Graha Ilmu.

Muchtar, Heri Jauhari. 2005. Fikih Pendidikan. Bandung: Remaja Rosdakarya.

Mulyasa, E. 2004 Menjadi Kepala Sekolah Professional, Bandung: PT Remaja Rosdakarya.

Mulyono. 2012. Educational Leadership. Malang: UIN-Malang Press.

Nizar, Samsul. 2008. Memperbincangkan Dinamika Intelektual dan Pemikiran Hamka tentang Pendidikan Islam. Jakarta: Kencana.

Qomar. 2009. Mujamil, Manajemen Pendidikan Islam, Jakarta: Erlangga.

Roqib, Moh. 2009. Ilmu Pendidikan Islam. Yogyakarta: LKiS Yogyakarta.

Saebani, Beni Ahmad. 2012. Filsafat Manajemen. Bandung: Pustaka Setia.

Umar, Bukhari. 2010. Ilmu Pendidikan Islam. Jakarta: Amzah.

Yunus, Mahmud. TT. Pokok-pokok Pendidikan dan Pengajaran. Jakarta: Hidakarya Agung.

Zainuddin, Muhadi dan Abd. Mustaqim. 2012. Studi Kepemimpinan Islam: Konsep, Teori, dan Praktiknya dalam Sejarah. Yogyakarta: SUKA-Press UIN Sunan Kalijaga. 